\title{
Credit off-take from formal financial institutions in rural India: quantile regression results
}

Debdatta Pal ${ }^{1 *}$ and Arnab Kumar Laha ${ }^{2}$

\author{
* Correspondence: \\ debdatta@iimraipur.ac.in \\ ${ }^{1}$ Economics and Business \\ Environment, Indian Institute of \\ Management Raipur, GEC Campus, \\ Raipur 352015, India \\ Full list of author information is \\ available at the end of the article
}

\begin{abstract}
Extending financial services to unbanked population in India has remained a central part of the policy thrust of the Indian government for decades. To that effect, a widespread formal credit delivery mechanism has been established to meet the credit requirements of rural communities. However, the Indian governmentbacked formal financial sector has had limited success in providing resources to poor rural households, which has led to strong criticism of the policy and its implementation. In this study, we use data from 600 rural households spread across six Indian states to examine the changing distribution of credit off-take among borrowers of formal financial institutions. By using quantile regression, we find that even among rural households that could access loans from the formal banking sector, the distribution of credit off-take is skewed towards resource-rich households. We also find that even among borrowers in the upper quantiles of the conditional loan distribution, marginal farmers received substantially less loan amounts than those belonging to the category of medium and large farmers.
\end{abstract}

JEL classifications: C31, Q14

Keywords: Rural credit; Formal finance; Quantile regression; India

\section{Background}

The policy thrust to make formal credit inclusive has been a central focus of the Indian government. This may be attributed to two widely accepted facts. First, access to credit is a precursor for growth, and second, alternative credit sources are costly. Policy-makers in India have long pushed the formal financial sector to open more outlets and bankers to offer credit below the market clearing price (Burgess and Pande 2005). However, since credit is an inter-temporal contract, lenders face the dual problem of adverse selection (hidden information) and moral hazard (hidden action). If lenders, through screening, cannot identify borrowers based on their likelihood of default, willful default may rise. In response to this, informal lenders may add a default premium on top of the nominal interest rate, an option that is unavailable to formal financial sources, where interest rates are controlled by the government (Gonzalez-Vega 1984). Hence, formal lenders, namely banks and cooperatives, may ration credit, request additional documents from and frequent visits by the borrower (leading to higher borrower-side transaction costs), demand marketable collateral, and favor production credit over consumption loan. The void created out of the unmet credit demand from formal financial sources has led to the widespread dependence of Indian rural households on informal credit sources, namely moneylenders and traders (see Basu 2006 for empirical evidence).

(C) 2014 Pal and Laha; licensee Springer. This is an open access article distributed under the terms of the Creative Commons Attribution License (http://creativecommons.org/licenses/by/2.0), which permits unrestricted use, distribution, and reproduction in any medium, provided the original work is properly cited. 
Academic inquiries to identify the causes of such dismal performance on the part of the formal financial sector in agrarian economies can be classified under three broad groups: first, those that attempt to identify factors affecting the choice of credit sectors in rural economies (see, for example, Kochar 1997; Pal 2002; Sahu et al. 2004; Boucher and Guirkinger 2007; Datta and Ghosh, 2013; Pal and Laha 2013), second, those that explore the determinants of credit amounts received by rural households from the formal sector (see, for example, Datta 2003; Sahu et al. 2004) and third, those that estimate the effects of the lack of access to formal-sector credit on agricultural production (Carter 1989; Guirkinger and Boucher 2008). The first two groups of empirical investigations indicate that a large agricultural land size, good land quality, the presence of irrigation and regarding the loan applicant, membership in a higher caste and higher levels of educational attainment increase the applicant's chance of gaining access to formal credit sources as well as the quantum of credit disbursed by the formal sector. The third set consists of a growing body of empirical literature that suggest that credit constraints adversely affect farm production, farm profit, and farm investment.

This study contributes additional empirical evidence to support the findings of the second set of inquiries and attempts to answer the following question: among the rural households that have received loans from the formal sector, what is the changing distribution of credit off-take? Finding an answer to this question is pertinent from the following policy perspectives. First, it would help central bankers as well as policy makers understand variations in outreach of the formal banking sector within its own client group. Secondly, it would elucidate the extent of the gap between the credit off-take from the formal financial sector by the rich and poor households in the context of a developing country like India. Moreover, apart from including those variables mentioned in earlier studies, namely Datta (2003) and Sahu et al. (2004), this study also attempts to capture the effects of village-level attributes, such as the distance of households from commercial, financial, and educational institutions, on the loan amount.

These findings would complement the theoretical model advanced by Nakamura and Nakajima (2011) which shows that improvements in the credit market during the early stages of economic development is essential to escape poverty.

We used quantile regression, which was introduced by Koenker and Bassett (1978), to address this issue of improving the credit off-take from formal financial sources in rural India. Quantile regression is used when conditional quantile functions and even extremes are of interest, and it has been used in various areas of applied economics, such as health economics (see Winkelmann 2006, for example), financial economics (see Bassett and Chen 2001, for example), labor economics (see Buchinsky 1998, for a detailed survey), and education economics (see Eide and Showalter 1998). To the best of our knowledge, quantile regression has not been employed thus far to study changes in the distribution of credit off-take by rural households. Consistent with the theory of credit rationing, we observed that between resource-rich and resource-poor rural households, there is considerable variation in the quantum of loan off-take from formal financial institutions. By using quantile regression, we found that among borrowers in the $90^{\text {th }}$ quantile of the conditional loan distribution, marginal farmers ${ }^{\mathrm{a}}$ received only approximately 80 percent of the loan amount of their counterparts belonging to the category of medium and large farmers. 
Briefly, the structure of this paper is as follows. In Survey and data description, we describe the survey and dataset. Method presents the methodology used for analysis. Results and discussion contains the results and discussion, and in Conclusions, we indicate the policy implications.

\section{Survey and data description}

The survey was conducted between May and December 2010 as part of the research project of the Centre for Management in Agriculture, Indian Institute of Management Ahmedabad, titled "Assessing Policy Interventions in Agri-Business and Allied Sector Credit versus Credit Plus Approach for Livelihood Promotion," sponsored by the Ministry of Agriculture, Government of India. Six Indian states-Chhattisgarh, Maharashtra, West Bengal, Andhra Pradesh, Tamil Nadu, and Gujarat-were selected based on two state-level indicator criteria: first, the average population per branch of formal financial institution as of the end of June 2009, and second, incidences of indebtedness of rural households. Table 1 shows these two indicators against the national average.

Against the national average of 6554 people per rural branch of formal financial institution attempt has been made to choose states with even spread on this criterion. While a bank branch caters to 10410 people on average in Chhattisgarh, the number of people served by a bank branch in Maharashtra is as low as 2688. The average population per bank branch in West Bengal is the closest to national average. Therefore, variation on the level of branch penetration is well maintained in the sample. Similarly, the sample states are distributed evenly above, below, and at the average for the criterion of incidences of indebtedness of rural households. Through this process, we attempted to capture variations among the sample states. To ensure that various lending institutions are represented, we selected a village or cluster of villages within a single agroclimatic region of a state where all credit sources, namely, formal, semi-formal, and informal, are present (see Additional file 1: Appendix 1). Formal lending institutions are scheduled public or private sector commercial banks ${ }^{c}(\mathrm{SCB})$, regional rural banks ${ }^{\mathrm{d}}$ (RRB), and cooperative banks, ${ }^{e}$ namely, primary agricultural cooperative societies (PACS), multipurpose PACS (MPACS), District Central Cooperative Bank (DCCB), and State Cooperative Banks. Semi-formal credit sources include self-help groups ${ }^{\mathrm{f}}$ (SHG) and microfinance institutions $^{\mathrm{g}}$ (MFI). The informal sector includes moneylenders, input dealers, output traders, shopkeepers, and friends and relatives. A complete enumeration of all

Table 1 Indicators of branch penetration and rural indebtedness

\begin{tabular}{lcccc}
\hline State & $\begin{array}{c}\text { Average population per rural } \\
\text { financial institution branch } \\
\text { as of March } \mathbf{2 0 0 9 ^ { \# }}\end{array}$ & \multicolumn{2}{c}{$\begin{array}{c}\text { Incidence of indebtedness of rural households } \\
\text { (in \%) as of June 2002 }\end{array}$} \\
\cline { 3 - 5 } & 10410 & 14.4 & 6.7 & All \\
\hline Chhattisgarh & 2688 & 22.8 & 7.2 & 19.8 \\
Maharashtra & 6095 & 12.1 & 11.0 & 27.5 \\
West Bengal & 11784 & 14.9 & 32.9 & 21.8 \\
Andhra Pradesh & 5976 & 13.9 & 21.3 & 42.3 \\
Tamil Nadu & 3759 & 14.7 & 15.8 & 31.3 \\
Gujarat & 6554 & 13.4 & 15.5 & 28.1 \\
\hline All of India & & &
\end{tabular}

"Authors' own calculation ${ }^{\text {b. }}$.

${ }^{\$}$ Household indebtedness in India as of 06.30 .02 (National Sample Survey Organisation 2005). 
households ${ }^{\mathrm{h}}$ in a village was undertaken to form a sampling frame that was used to draw a representative sample of village households.

The survey was conducted in five villages in West Bengal, three villages each in Maharashtra and Chhattisgarh, and one village each in Andhra Pradesh, Gujarat, and Tamil Nadu. From each village in West Bengal, 30 households were chosen through random sampling, whereas in the other states, 50 households were randomly chosen from each village. Thus, the total sample size in this study consists of 600 households. Each sample household was administered a structured questionnaire to collect general information on household demographics, social characteristics, occupation (both primary and secondary), resource endowment, loan-related information (i.e., access to different credit sources between April 2009 and March 2010), and the terms and conditions of the loan facilities experienced by the borrowers.

Incidentally, besides respondents that borrowed from mutually exclusive sources (i.e., formal, semi-formal, or informal), this survey also included those that borrowed from multiple sources. Of the 600 sampled households, 231 met their full credit demand entirely from formal sources, 129 met part of their credit demand from formal sources, 91 respondents were excluded from formal sources but have used credit facilities from semi-formal and/or informal sources, 71 were dependent solely on informal credit sources, and 75 respondents did not avail any credit facilities during the corresponding period (see Table 2).

Of the 600 households, 525 availed themselves of at least one credit facility during April 2009 to March 2010. Out of these 525 borrower households, 293 households have used only one loan during this period. During the corresponding period, the numbers of households with two, three, and four loans are 140, 53, and 39, respectively. Therefore, the total number of loan cases gathered from this survey is 888 (see Table 3).

Of the 888 loan cases considered, 399 loans were offered by formal credit sources, 109 loans by semi-formal sources, and the remaining 370 loans by the informal sector. We followed the coding pattern suggested by Walter et al. (1987), which is given in Additional file 2: Appendix 2. To elucidate the characteristics of the villages and households covered in this study, we report summary statistics in Table 4.

\section{Method}

The analysis is based on 399 loan contracts extended by the formal financial sector among the 600 sample households. Earlier analyses (see, Datta 2003; Sahu et al. 2004)

Table 2 Categories of households based on loan sources

\begin{tabular}{|c|c|c|c|}
\hline \multicolumn{3}{|c|}{ Source of loan } & \multirow[t]{2}{*}{ Category of household } \\
\hline Formal & Semi-formal & Informal & \\
\hline Yes & No & No & Households met their full credit demand entirely from the formal sector \\
\hline Yes & Yes & No & \multirow[t]{3}{*}{ Households met part of their credit demand from the formal sector } \\
\hline Yes & No & Yes & \\
\hline Yes & Yes & Yes & \\
\hline No & Yes & No & \multirow{2}{*}{$\begin{array}{l}\text { Households excluded from the formal sector but which used credit } \\
\text { facilities from semi-formal and/or informal sectors }\end{array}$} \\
\hline No & Yes & Yes & \\
\hline No & No & Yes & Households solely dependent on the informal sector \\
\hline No & No & No & Households without any credit facilities \\
\hline
\end{tabular}


Table 3 Distribution of loans across households

\begin{tabular}{cccc}
\hline Number of loans received during 2009-10 & Number of households & Total loans \\
\hline 1 & 293 & 293 \\
& 2 & 140 & 280 \\
3 & 53 & 159 \\
& 4 & 39 & 156 \\
\hline Total & 525 & 888 \\
\hline
\end{tabular}

of the determinants of the loan amount $(Y)$ from the formal sector used ordinary least squares (OLS) regression methods. However, these OLS estimates of the various effects on the conditional mean of the loan amount, $E(Y \mid$ covariates $)$, may not truly represent the nature and size of those effects on the lower tail of the loan amount distribution.

Here, we deviate from the earlier approach and use quantile regression (see, Koenker and Bassett 1978; Koenker 2005), which models the dependence of the conditional quantiles of $Y$ given the covariates. This is helpful in models wherein extremes are vital. Here, quantile regression is expected to yield a comprehensive picture of the conditional distribution of loan off-take from formal creditors by rural customers given different village, household, and loan attributes for both the lower and upper quantiles.

Let $\left(y_{i}, \boldsymbol{x}_{i}\right), i=1, \ldots, n$, be a sample from a population, where $\boldsymbol{x}_{i}$ is a $(K \times 1)$ vector of regressors. Assuming that the $\tau^{\text {th }}$ quantile of the conditional distribution of $y_{i}$ is linear in $\boldsymbol{x}_{i}$, let us denote $\xi\left(\boldsymbol{x}_{i}, \boldsymbol{\beta}_{\tau}\right)$ as the $\tau^{\text {th }}$ quantile of the distribution of $y_{i} \mid \boldsymbol{x}_{i}$. That is,

$$
\xi\left(\boldsymbol{x}_{i}, \boldsymbol{\beta}_{\tau}\right) \equiv \inf \left[y: F_{i}(y \mid \boldsymbol{x}) \geq \tau\right]
$$

Then, we assume that $\xi\left(\boldsymbol{x}_{i}, \boldsymbol{\beta}_{\tau}\right)=\boldsymbol{x}_{i}^{\prime} \beta_{\tau}$, where, $\boldsymbol{\beta}_{\tau}$ is the unknown vector of parameters to be estimated for varying values of $\tau$ where $0<\tau<1$. By changing the value of $\tau$, the entire distribution of $y$ conditional on $\boldsymbol{x}$ can be traced. The estimator for $\boldsymbol{\beta}_{\tau}$ comes from:

$$
\min \sum_{\mathrm{i}}^{n} \rho_{\tau}\left(y_{i}-\boldsymbol{x}_{i}^{\prime} \boldsymbol{\beta}_{\tau}\right)
$$

where $\rho_{T}(u)$ denotes the function defined as

$$
\rho_{\tau}(u)= \begin{cases}\tau u & \text { if } u \geq 0 \\ (\tau-1) u & \text { if } u<0\end{cases}
$$

For further details, see Koenker (2005), pp. 28-67. In this study, values of $\tau$ are taken as $\frac{1}{10}, \frac{1}{2}$, and $\frac{9}{10}$, which results in the $10^{\text {th }}$ quantile, median, and $90^{\text {th }}$ quantile, respectively. Here, $y_{i}$ is the amount of loan received by the sampled rural households from formal credit sources during 2009-10, and $\boldsymbol{x}_{i}$ is a vector of independent variables describing the village, household, and loan characteristics.

\section{Results and discussion}

As an outcome of the exchange mechanism, a credit transaction is governed not only by the demand for credit but also by the lender's willingness to extend credit. Furthermore, being an inter-temporal transaction, credit exposes the lender to postcontractual default risks. Therefore, the lender would take utmost care to ensure timely repayment of his or her dues. Hence, it is likely that the formal lender will consider a 
Table 4 Summary statistics of exogenous variables used in the empirical analysis

\begin{tabular}{|c|c|c|c|c|c|}
\hline \multicolumn{6}{|l|}{ A } \\
\hline Variable & Definition of variable & Mean & Minimum & Maximum & $\mathbf{n}$ \\
\hline PIRRI & $\begin{array}{l}\text { Percentage of agricultural land under } \\
\text { assured irrigation in a particular village }\end{array}$ & 58.60 & 0 & 100 & 14 \\
\hline PELECTRIC & $\begin{array}{l}\text { Percentage of households having access to } \\
\text { electricity in a particular village }\end{array}$ & 72.73 & 3 & 98 & 14 \\
\hline AGRI & $\begin{array}{l}\text { Average distance (in km) from agricultural } \\
\text { infrastructures (e.g., Agriculture Produce } \\
\text { Marketing Committee sub-yard, office of } \\
\text { extension service providers, agricultural } \\
\text { input retailers, and farm machinery dealers) }\end{array}$ & 5.15 & 0.83 & 10.33 & 14 \\
\hline EDU & $\begin{array}{l}\text { Average distance (in } \mathrm{km} \text { ) from educational } \\
\text { institutions }\end{array}$ & 2.23 & 0 & 6.5 & 14 \\
\hline FININS & $\begin{array}{l}\text { Average distance (in km) from formal } \\
\text { financial institutions (e.g., commercial banks } \\
\text { and cooperatives) }\end{array}$ & 3.76 & 0 & 8.33 & 14 \\
\hline FAMTOT & $\begin{array}{l}\text { Number of key social leaders (e.g., Panchayat } \\
\text { Pradhani, government extension officers, } \\
\text { local school head masters, and financial } \\
\text { institution officials) whom the household } \\
\text { is familiar with }\end{array}$ & 3.95 & 0 & 7 & 600 \\
\hline LOANAMT & $\begin{array}{l}\text { Amount (in Indian Rupee - INR') of loan } \\
\text { made available }\end{array}$ & 20656.19 & 200 & 600000 & 888 \\
\hline TCOST & Borrower's total transaction cost in INR & 246.89 & 0 & 2960 & 888 \\
\hline RAINT & Annualized interest rate in reducing balance & 18.47 & 0 & 61 & 888 \\
\hline \multicolumn{6}{|l|}{ B } \\
\hline \multirow[t]{2}{*}{ Variable } & Definition of variable & \multicolumn{3}{|c|}{ Frequency } & \multirow[t]{2}{*}{ Cumulative } \\
\hline & & 1 & & 0 & \\
\hline CASTRDUM & $\begin{array}{l}\text { Caste and religion:1 = Upper caste Hindu, } \\
0=\text { Otherwise (Lower caste Hindu and } \\
\text { minorities, such as Muslims) }\end{array}$ & $186(31.00)$ & \multicolumn{2}{|c|}{$414(69.00)$} & $600(100)$ \\
\hline LANDD1 & $\begin{array}{l}\text { Household is minimum from marginal } \\
\text { farmer category }(\mathrm{Yes}=1, \mathrm{No}=0 \text { ) }\end{array}$ & $536(89.33)$ & \multicolumn{2}{|c|}{$64(10.67)$} & $600(100)$ \\
\hline LANDD2 & $\begin{array}{l}\text { Household is minimum from small farmer } \\
\text { category }(Y e s=1, \mathrm{No}=0)\end{array}$ & $199(33.17)$ & \multicolumn{2}{|c|}{$401(66.83)$} & $600(100)$ \\
\hline LANDD3 & $\begin{array}{l}\text { Household is minimum from medium/large } \\
\text { farmer category }(\mathrm{Yes}=1, \mathrm{No}=0)\end{array}$ & $69(11.50)$ & \multicolumn{2}{|c|}{$531(88.50)$} & $600(100)$ \\
\hline IRRISTATD1 & $\begin{array}{l}\text { At least a part of the agricultural land of the } \\
\text { household has assured irrigation } \\
\text { (Yes }=1, \mathrm{No}=0 \text { ) }\end{array}$ & $343(57.17)$ & \multicolumn{2}{|c|}{$257(42.83)$} & $600(100)$ \\
\hline IRRISTATD2 & $\begin{array}{l}\text { Agricultural land of the household is } \\
\text { covered under assured irrigation } \\
\text { (Yes }=1, \mathrm{No}=0 \text { ) }\end{array}$ & $188(31.33)$ & \multicolumn{2}{|c|}{$412(68.67)$} & $600(100)$ \\
\hline ALACDUM & $\begin{array}{l}\text { Household engaged in allied activity as } \\
\text { fisheries/orchard/farm forestry } \\
\text { (Yes }=1, \text { No }=0 \text { ) }\end{array}$ & $93(15.50)$ & \multicolumn{2}{|c|}{$507(84.50)$} & $600(100)$ \\
\hline DWELLD1 & $\begin{array}{l}\text { Household possesses at least a mud built } \\
\text { house (Yes }=1, \mathrm{No}=0)\end{array}$ & $580(96.67)$ & \multicolumn{2}{|c|}{$20(3.33)$} & $600(100)$ \\
\hline DWELLD2 & $\begin{array}{l}\text { Household possesses at least a mud and } \\
\text { brick built house }(\mathrm{Yes}=1, \mathrm{No}=0)\end{array}$ & $285(47.50)$ & \multicolumn{2}{|c|}{$315(52.50)$} & $600(100)$ \\
\hline DWELLD3 & $\begin{array}{l}\text { Household possesses a brick built house } \\
(\text { Yes }=1, \mathrm{No}=0)\end{array}$ & $74(12.33)$ & \multicolumn{2}{|c|}{$426(87.67)$} & $600(100)$ \\
\hline SANITD1 & Household having at least an open toilet & $438(73.00)$ & \multicolumn{2}{|c|}{$162(27.00)$} & $600(100)$ \\
\hline
\end{tabular}
$($ Yes $=1, \mathrm{No}=0)$ 
Table 4 Summary statistics of exogenous variables used in the empirical analysis (Continued)

\begin{tabular}{llccc}
\hline SANITD2 & $\begin{array}{l}\text { Household with modern toilet facility } \\
(\text { Yes }=1, \mathrm{No}=0)\end{array}$ & $271(45.17)$ & $329(54.83)$ & $600(100)$ \\
PURPDUM & $\begin{array}{l}\text { Loan is for production purpose } \\
(\text { Yes }=1, \mathrm{No}=0)\end{array}$ & $525(59.12)$ & $363(40.88)$ & $888(100)$ \\
SECDUM & $\begin{array}{l}\text { Loan is secured by marketable collateral } \\
(\text { Yes }=1, \mathrm{No}=0)\end{array}$ & $294(33.11)$ & $594(66.89)$ & $888(100)$ \\
\hline
\end{tabular}

Note: Figures in parentheses are percentages.

variety of factors before deciding to approve a loan application. Further, for the loan applicant, the quantum of loan requirement would also be dependent on various factors. Below, we describe these factors and their relationship to the chance of loan approval by a formal lender as well as to the quantum of loan requirement.

\section{Factors affecting the supply of credit}

Since credit is extended to agricultural households who borrow on the basis of their land holding, such land holding acts as collateral from the lender's perspective. The lender is assured that borrowers with a larger acreage of land would produce sufficient output to generate income to repay loans without difficulty. An assured irrigation facility increases the reliability of higher crop production and is, in turn, associated with a higher profit potential of the farmer applicant. This would be perceived positively by the lender and would carry a higher probability that loan applications for higher amounts will be considered favorably by the formal lender. Lenders may also prefer households that engage in allied activities such as cattle rearing and fishery, which are alternative earning sources to farming, as such activities may lower the probability of default in the event of crop failure. Access to information from extension agents is expected to help farmers adopt improved farming technology, thereby increasing the probability of higher yields. Lenders may prefer farmers with a possibility of registering more income from higher yields.

The possession of landed house property as well as in-house toilet facilities would signal a resource-rich household in rural India, thereby increasing the household's chance of receiving a higher amount in loans from the formal lender. Familiarity with key social leaders is expected to improve the credentials of the loan applicant and, hence, may be considered favorably by the formal lender. Since large tracks of land are traditionally owned by resource-rich upper caste Hindu families in India, belonging to such a family may also create a favorable impression on the lender.

Indeed, banks may prefer households from villages with a higher coverage of assured irrigation and access to electrical power, as farmers from those villages are expected to undertake multiple-cropping and thus carry better profit potential as compared to households that do not have access to such public infrastructure support. Villages closer to agricultural infrastructure carry higher business potential and, thus, may be favored by formal lenders. Furthermore, proximity to formal financial institutions is expected to lead to a wider outreach of financial services as a result of minimum transaction costs incurred by the lender to service those clients. Banks may also prefer to lend in villages closer to educational institutions, as those villages would have a higher 
number of educated households, who may use loan funds more judiciously and carry better employability in non-farm sectors and, hence, have sufficient income to repay loans.

Lastly, formal creditors would prefer to lend for the purpose of production over that of consumption, since the former is associated with the possibility of generating positive surplus required to meet debt obligations.

\section{Factors affecting the demand for credit}

A large track of land with a good irrigation facility not only extends a positive signal to the formal lender but it also boosts the demand for credit to meet higher production expenses incurred from the purchase of improved varieties of seeds and other inputs, wage payments to laborers, the rental of agricultural machinery such as tractors, and electricity charges. Moreover, households with allied activities such as cattle rearing and fishery could assume a higher debt exposure, as income from alternative sources would act as a contingency for avoiding any default risks in the event of production failure. Households with access to information from extension agents are expected to adopt improved farming technology, thus, they may require a higher quantum of loan to meet higher production costs. Furthermore, upper caste Hindu families with large land holdings may demand higher loan amounts to meet higher costs of cultivation.

Peasant households belonging to villages with access to assured irrigation and electrical power are expected to undertake multiple-cropping and thus require a higher amount in loans compared to villagers farming under rain-fed mono-cropping systems. Villages closer to agricultural infrastructures are expected to carry a higher business potential and are therefore more likely to borrow money for expanding agricultural or other business activities. In addition, agricultural households from villages located near formal financial institutions are expected to perform more transactions and avail themselves of a higher quantum of loans due to the minimum transaction costs involved in dealing with formal lenders. Similarly, villages located near educational institutions are expected to have a higher number of educated households that are more informed about the lending process of formal financial institutions and thus have a better scope of obtaining higher loan amounts from the formal sector.

Households may apply for loans for agricultural production or other purposes, namely consumption purpose. Such loans may or may not be backed by marketable collateral. These, as well as the total ex ante monetary costs involved in negotiating the loan and annual interest rates, represent loan attributes that may affect both access to credit from the formal lender and the quantum of loan.

The variable definitions given in Table 4 include all of the variables mentioned above.

Initially, we outlined the effects of these variables on the loan amount, by using OLS. Next, three quantile regression models, for the $10^{\text {th }}$ quantile, $50^{\text {th }}$ quantile, and $90^{\text {th }}$ quantile, were fitted with the loan amount as the dependent variable and the various village, household, and loan attributes as explanatory variables. The model parameters were estimated using the PROCREG and QUANTREG procedures of the SAS software.

State-level variations in both OLS and quantile regression were captured by state dummies. Although data were collected from 3-5 villages for Chhattisgarh, Maharashtra, and West Bengal, these villages are from a single cluster of an agro-climatic region. 
Hence, we assume that the state-level dummy would be sufficient for capturing variability across villages.

\section{Results of OLS regression analysis}

The results of the OLS estimates are presented in Table 5. As expected, the presence of irrigation facilities and electrical power in a borrower's village positively boosted the credit off-take from formal financial institutions in that village. Close proximity of the borrower's village to formal financial institutions positively affected the loan amount, as expected. However, close proximity of the borrower's village to agricultural markets

Table 5 Ordinary Least Squares estimates of the linear regression model for loan amount

\begin{tabular}{|c|c|c|}
\hline \multirow[t]{2}{*}{ Explanatory variables } & \multicolumn{2}{|c|}{ Parameter estimates } \\
\hline & Coefficient & SE \\
\hline Intercept & $-209997^{* * *}$ & 44913.00 \\
\hline \multicolumn{3}{|l|}{ State dummy ${ }^{1}$} \\
\hline Chhattisgarh (CGARH) & $-32785^{*}$ & 16763.00 \\
\hline Maharashtra (MAHA) & $-44746^{* * *}$ & 15840.00 \\
\hline West Bengal (WB) & -34541 & 23433.00 \\
\hline Andhra Pradesh (AP) & $-81708^{* * *}$ & 20033.00 \\
\hline Tamil Nadu (TN) & $-109030^{* * *}$ & 22474.00 \\
\hline \multicolumn{3}{|l|}{ Village attribute } \\
\hline PIRRI & $579.48^{*}$ & 328.02 \\
\hline PELECTRIC & $1211.24^{* * *}$ & 312.82 \\
\hline AGRI & 3075.69 & 4648.62 \\
\hline EDU & $8582.52^{*}$ & 4590.04 \\
\hline FININS & -3606.29 & 4264.39 \\
\hline \multicolumn{3}{|l|}{ Household attribute } \\
\hline LANDD1 & 1342.84 & 15353.00 \\
\hline LANDD2 & 7719.08 & 6557.80 \\
\hline LANDD3 & $28154^{* * *}$ & 8522.69 \\
\hline IRRISTATD1 & 2773.70 & 9178.17 \\
\hline ALACDUM & $26352^{* *}$ & 10331.00 \\
\hline INFORDUM & $-25485^{*}$ & 7113.22 \\
\hline DWELLD2 & -9211.10 & 7991.39 \\
\hline SANITD1 & 11445 & 8177.80 \\
\hline FAMTOT & $5151.78^{* *}$ & 2239.92 \\
\hline CASTRDUM & $15235^{*}$ & 8132.51 \\
\hline \multicolumn{3}{|l|}{ Loan attribute } \\
\hline PURPDUM & 9801.21 & 11864.00 \\
\hline SECDUM & $15093^{* *}$ & 6910.41 \\
\hline TCOST & $54.15^{* * *}$ & 7.91 \\
\hline RAINT & $7745.93^{* * *}$ & 1234.58 \\
\hline R-square & & 0.5224 \\
\hline Number of observations & & 399 \\
\hline
\end{tabular}

***Significant at a level of 1 percent; ** significant at a level of 5 percent; *significant at a level of 10 percent significance. ${ }^{1}$ Gujarat (GUJ) state was used as the base state in this analysis. 
and educational institutions in this OLS regression was found to negatively affect borrowing from the formal sector.

Unsurprisingly, farm households with a minimum of two hectares of land were found to be favored by formal lenders. Assured irrigation facilities do have a positive effect on the approval of loans from formal lenders. Moreover, households with additional income from allied activities were able to borrow greater amounts in loans from formal lenders. Familiarity with key social leaders, as expected, may have established a borrower's credentials on a strong footing for the formal lenders, therefore, these households could obtain higher amounts in loans from banks. Agricultural households belonging to the upper caste Hindu community, which traditionally controlled better production resources, attracted big ticket loans, as expected. In addition, formal lenders met the higher credit demands of households who asked for production loans and who offered marketable security to obtain such loans.

The above analysis is based on OLS regression analysis, which estimates the average loan amount from the financial sector, conditional on the covariates.

\section{Results of quantile regression analysis}

The next model, which concerns the estimates of loan amounts across quantiles, is presented in Table 6. As quantile regression analysis estimates the total loan amount in various conditional quantiles, we can develop more detailed and accurate information from different borrower groups, depending on the loan amount. We estimated three separate quantile levels, 10 percent, 50 percent, and 90 percent.

Here, we compared the results of the OLS regression with that of the quantile regression at three levels (i.e., $10^{\text {th }}$ quantile, $50^{\text {th }}$ quantile, and $90^{\text {th }}$ quantile). We also checked whether the direction of the explanatory variables changed over quantiles and tried to interpret possible reasons for such variations across the borrower groups.

The extent of coverage of irrigation facilities in the sample villages was observed to have positively boosted the credit off-take from formal financial institutions across all quantiles, a result that is similar to the one in the OLS estimate. The extent of electrical power coverage, as expected, was found to have a positive and significant effect on loan amounts in both the $50^{\text {th }}$ and $90^{\text {th }}$ quantiles, which is in line with the OLS regression results. However, this independent variable was observed to have a negative effect on loan amounts in the $10^{\text {th }}$ quantile. As one of the major uses of electricity in an agrarian economy is to supply power for mechanized water extraction, it seems plausible as households with loan amounts in the $10^{\text {th }}$ quantile (i.e., with smaller loan amounts) may have used the groundwater-based irrigation facilities of affluent larger farmers on a payment basis, rather than possessing their own pumps.

Close proximity to agricultural infrastructures such as markets, contrary to expectation, was observed to affect the loan amount across the three quantiles negatively. The same variable was also shown to carry a negative effect on the loan amount in the OLS regression. This may be a result of a common practice in Indian villages, wherein traders pick up produce from farm gates. While the farmers save transaction costs in the form of transportation and wage loss, traders benefit from scale 
Table 6 Estimated Quantile Regression models for different quantiles of loan amount

\begin{tabular}{|c|c|c|c|c|c|c|}
\hline \multirow[t]{3}{*}{ Explanatory variables } & \multicolumn{6}{|c|}{ Parameter estimates } \\
\hline & \multicolumn{2}{|c|}{ 10th quantile } & \multicolumn{2}{|l|}{ 50th quantile } & \multicolumn{2}{|c|}{ 90th quantile } \\
\hline & Coefficient & SE & Coefficient & SE & Coefficient & SE \\
\hline Intercept & -3023.04 & 6145.14 & $-58343.10^{* * *}$ & 14224.51 & $-147202^{* * *}$ & 48695.88 \\
\hline \multicolumn{7}{|l|}{ State dummy ${ }^{1}$} \\
\hline CGARH & -129.87 & 2022.37 & $-19829.60^{* * *}$ & 5339.15 & $-125685^{* * *}$ & 20686.72 \\
\hline MAHA & $4978.60^{* *}$ & 2350.93 & $-13951.00^{* *}$ & 5607.84 & $-119181^{* * *}$ & 20987.51 \\
\hline WB & -3981.68 & 3444.37 & $-26902.60^{* * *}$ & 7848.67 & $-136140^{* * *}$ & 30152.03 \\
\hline AP & -934.78 & 4145.60 & $-41410.40^{* * *}$ & 6103.54 & $-146031^{* *}$ & 66209.14 \\
\hline TN & $8821.28^{*}$ & 4719.19 & $-29652.00^{* * *}$ & 7069.57 & $-185739^{* * *}$ & 29719.60 \\
\hline \multicolumn{7}{|l|}{ Village attribute } \\
\hline PIRRI & 79.70 & 52.57 & $277.56^{* * *}$ & 92.58 & $840.77^{* *}$ & 357.02 \\
\hline PELECTRIC & -20.76 & 44.68 & $277.56^{* * *}$ & 97.64 & $939.31^{* *}$ & 367.13 \\
\hline AGRI & 804.46 & 761.64 & $2684.61^{* *}$ & 1170.26 & 6420.22 & 4443.15 \\
\hline EDU & -264.58 & 664.07 & $2902.40^{* * *}$ & 987.40 & 8018.66 & 5027.19 \\
\hline FININS & -919.00 & 649.98 & $-2713.70^{* * *}$ & 999.26 & $-11031^{* * *}$ & 4025.82 \\
\hline \multicolumn{7}{|l|}{ Household attribute } \\
\hline LANDD1 & 123.54 & 2446.33 & $-8176.26^{* *}$ & 3462.95 & -1756.14 & 14581.15 \\
\hline LANDD2 & 838.44 & 1159.54 & $5606.88^{* * *}$ & 1656.78 & 9743.56 & 6883.54 \\
\hline LANDD3 & 2439.05 & 1711.23 & $5507.91^{* *}$ & 2679.73 & $47032.80^{* * *}$ & 16963.92 \\
\hline IRRISTATD1 & -500.14 & 1332.19 & $5328.91^{* *}$ & 2351.58 & 6506.94 & 8388.00 \\
\hline ALACDUM & 52.82 & 1476.04 & $4681.41^{*}$ & 2605.45 & $29196.12^{* *}$ & 12611.03 \\
\hline INFORDUM & -631.00 & 1218.70 & $-4227.71 * *$ & 1983.89 & $-14808.40^{* *}$ & 7058.17 \\
\hline DWELLD2 & 17.16 & 1134.54 & -2243.86 & 1578.45 & $-13336.90^{*}$ & 8157.36 \\
\hline SANITD1 & 341.14 & 1112.72 & $5740.65^{* * *}$ & 1616.22 & $19080.75^{* * *}$ & 7270.81 \\
\hline FAMTOT & 100.91 & 270.96 & $2048.82^{* * *}$ & 610.63 & $4138.44^{*}$ & 2414.25 \\
\hline CASTRDUM & 911.02 & 1180.00 & $4869.94^{* *}$ & 2062.23 & $18121.14^{* *}$ & 9362.52 \\
\hline \multicolumn{7}{|l|}{ Loan attribute } \\
\hline PURPDUM & $-3536.50^{* * *}$ & 1348.02 & $7996.44^{* * *}$ & 2967.14 & $58381.59^{* * *}$ & 12673.53 \\
\hline SECDUM & 380.90 & 955.75 & $5133.02^{* * *}$ & 1752.80 & $20225.97^{* * *}$ & 6662.52 \\
\hline TCOST & 9.23 & 2.52 & $21.26^{* * *}$ & 4.22 & $64.07^{* * *}$ & 20.64 \\
\hline RAINT & 656.33 & 217.79 & $2804.72^{* * *}$ & 450.08 & $9272.05^{* * *}$ & 1929.91 \\
\hline Wald test & & 13.4542 & & 25.4063 & & 9.6373 \\
\hline Likelihood ratio $x^{2}(16)$ & & 32.6728 & & 59.4395 & & 72.8337 \\
\hline Number of observations & & 399 & & 399 & & 399 \\
\hline
\end{tabular}

***Significant at a level of 1 percent; ${ }^{* *}$ significant at a level of 5 percent; ${ }^{*}$ significant at a level of 10 percent significance. ${ }^{1}$ Gujarat (GUJ) state was used as the base state in analysis.

economics derived from the number of transactions from the same village as well as an assured supply of produce. Thus, even being far away from agricultural infrastructures such as markets, farmers would enjoy favor from formal lenders. Close proximity to formal financial institutions, as expected, boosted the loan off-take from the formal sector across quantiles and was significant at both the 50 percent and 90 percent levels. This regressor also had a similar effect on the regressand in the OLS regression. 
Land holding, as expected, was also observed to have a positive and significant effect on loan amounts, which is in line with the OLS estimation results. While at the median level, households with a minimum of one hectare of land became significant, at the $90^{\text {th }}$ quantile level, land holdings of a minimum of two hectares were shown to be significant. This clearly indicates that borrower households with larger operational land holdings are given larger loans from formal creditors. Availability of assured irrigation had a negative though insignificant effect on the loan amount in the lower quantile but a positive and significant effect at the median level. This may be explained by the possibility that households with lesser loan amounts are also marginal or tenant farmers who engage in cultivation during rainy seasons only. Because of the costly nature of crop cultivation during the winter season, such farmers may not be involved in winter crop production, which is dependent primarily on irrigation, and they may be working as wage laborers in the fields of large farmers. Unsurprisingly, alternative income from allied activities boosted the loan off-take from formal financial institutions, a result that is observed both in the OLS and across quantiles. Familiarity with key social leaders was also found to have a positive effect on the loan amount in all three quantiles, as expected. Belonging to the upper-caste Hindu community had a positive effect on the loan amount in all three quantiles but gained statistical significance in the $50^{\text {th }}$ and $90^{\text {th }}$ quantiles only. Both variables also showed a positive and significant effect on formal sector loans in the OLS framework.

Borrowing for production purposes was found to have a positive and statistically significant effect on loan amounts in the OLS and under quantile regression at the 50 percent and 90 percent levels. Interestingly, this variable showed a negative and significant effect on the loan amount in the $10^{\text {th }}$ quantile. This may be attributed to the provision of a small quantum of loans from the formal sector for consumption purposes, which is non-productive in nature. It is worth noting that formal credit sources resort primarily to project-based lending, where there is visible cash flow and adequate surplus to meet debt obligations. The formal sector's appetite for collateral-backed finance was reflected in both the OLS and quantile regression, as availability of collateral was shown to have a positive and significant effect on the loan amount.

We also found that larger loan sizes were positively and significantly associated with higher transaction costs, which means that borrowers may need to incur considerable expenses in frequent visits to bank branches to obtain credit facilities. Furthermore, higher interest rates were found to have a positive and significant effect on loan size. This may be due to prevailing interest rate regulations where, within an interest cap, banks charge more on higher credit limits. These trends were observed in both the OLS and quantile regression (for the $50^{\text {th }}$ and $90^{\text {th }}$ quantiles). Both variables have a positive (though statistically insignificant) effect on loan amounts at the 10 percent level under quantile regression.

The coefficients of the explanatory variables across the $10^{\text {th }}, 50^{\text {th }}$, and $90^{\text {th }}$ quantiles in the quantile regression are listed in Table 6, which indicates the variations in loan off-take from formal credit sources across borrower categories (i.e., marginal farmer, small farmer, and medium and large farmers. Because of the ordinal nature of this variable, the category of landless farmer was included as the reference category. We discuss 
the findings of this study by illustrating two situations, one favorable and the other unfavorable.

Suppose agricultural household type $A$, which has more than two hectares of land, hails from a relatively prosperous village in Chhattisgarh state. In this village, 90 percent of the agricultural land has access to assured irrigation and the same percentage of households have access to electrical power. The village is located near critical infrastructures, such as agricultural input and output markets, educational institutions, and financial institutions, with the average distance between the village and these facilities being $4 \mathrm{~km}, 2 \mathrm{~km}$, and $2 \mathrm{~km}$, respectively. Household type $A$ belongs to the upper caste Hindu community, enjoys assured irrigation for its agricultural land, is engaged in allied activity, possesses a brick house, and has in-house toilet facilities. The household is familiar with four key social leaders and receives information on agricultural activity from extension agents. It can receive a loan for agricultural production at an annual interest rate of 4 percent. For negotiating this loan contract, this household must incur an ex ante transaction cost of INR 300, and because of the household's higher profit potential, it could receive this loan facility without offering any marketable collateral.

In contrast, suppose agricultural household type $B$, which has less than one hectare of land, hails from a backward village in Chhattisgarh state. In this village, only 50 percent of the agricultural land has assured irrigation, and an equal percentage of households have electrical power. The village is located far from critical infrastructures such as agricultural input and output markets, educational institutions, and formal financial institutions, with the average distance between the village and these facilities being $10 \mathrm{~km}, 6 \mathrm{~km}$, and $8 \mathrm{~km}$, respectively. Household type $B$ belongs to either a lower caste Hindu or minority community, has only a part of its land under irrigation, is not involved in allied activities, and lives in a mud house without in-house toilet facilities. The household is familiar with only two key social leaders and does not receive any information about production activity from extension agents. It can receive a loan for production facility at an annual interest rate of 10 percent. To access this loan facility, household type $B$ has to bear an ex ante transaction cost of INR 500, and because of its poor profit potential, the household must arrange marketable collateral to receive the loan from the formal sector.

Table 7 shows six cases in each state, along with their corresponding $10^{\text {th }}$ quantile, $50^{\text {th }}$ quantile, and $90^{\text {th }}$ quantile of the conditional distribution of the loan amount. These six cases comprise both the favorable and unfavorable conditions described above across the categories of marginal, small, and medium and large farmers. Thus, there are a total of 30 cases across the five states.

In Table 7, we see from Case 1 that the middle 80 percent of type $B$ households have a loan off-take between INR 7089 and INR 75653, with a median off-take of INR 30934. From Case 6, we observe that in contrast to type $B$ households, 80 percent of type $A$ households have a loan off-take between INR 7894 and INR 130012, with a median off-take of INR 36351. We see that there is considerable variation in the amount of loan off-take among both types of households, with the variation being larger for type $A$ households. Being resource rich, type $A$ households are able to negotiate a higher amount in loans. This stands to be 17.5 percent if we compare the median off-take for both types of households. This is troubling from a state-policy 
Table 7 Loan amount across quantiles under varying situations

\begin{tabular}{|c|c|c|c|c|c|c|c|c|c|c|c|c|}
\hline Case no. & State & PIRRI & AGRI & EDU & FININS & PELECTRIC & LANDD1 & LANDD2 & LANDD3 & IRRISTATD1 & ALACDUM & INFORDUM \\
\hline 1 & CGARH & 50 & 10 & 6 & 8 & 50 & Yes & & & Yes & No & No \\
\hline 2 & CGARH & 50 & 10 & 6 & 8 & 50 & & Yes & & Yes & No & No \\
\hline 3 & CGARH & 50 & 10 & 6 & 8 & 50 & & & Yes & Yes & No & No \\
\hline 4 & CGARH & 90 & 4 & 2 & 2 & 90 & Yes & & & Yes & Yes & Yes \\
\hline 5 & CGARH & 90 & 4 & 2 & 2 & 90 & & Yes & & Yes & Yes & Yes \\
\hline 6 & CGARH & 90 & 4 & 2 & 2 & 90 & & & Yes & Yes & Yes & Yes \\
\hline 7 & MAHA & 50 & 10 & 6 & 8 & 50 & Yes & & & Yes & No & No \\
\hline 8 & MAHA & 50 & 10 & 6 & 8 & 50 & & Yes & & Yes & No & No \\
\hline 9 & MAHA & 50 & 10 & 6 & 8 & 50 & & & Yes & Yes & No & No \\
\hline 10 & MAHA & 90 & 4 & 2 & 2 & 90 & Yes & & & Yes & Yes & Yes \\
\hline 11 & MAHA & 90 & 4 & 2 & 2 & 90 & & Yes & & Yes & Yes & Yes \\
\hline 12 & MAHA & 90 & 4 & 2 & 2 & 90 & & & Yes & Yes & Yes & Yes \\
\hline 13 & WB & 50 & 10 & 6 & 8 & 50 & Yes & & & Yes & No & No \\
\hline 14 & WB & 50 & 10 & 6 & 8 & 50 & & Yes & & Yes & No & No \\
\hline 15 & WB & 50 & 10 & 6 & 8 & 50 & & & Yes & Yes & $\mathrm{No}$ & No \\
\hline 16 & WB & 90 & 4 & 2 & 2 & 90 & Yes & & & Yes & Yes & Yes \\
\hline 17 & WB & 90 & 4 & 2 & 2 & 90 & & Yes & & Yes & Yes & Yes \\
\hline 18 & WB & 90 & 4 & 2 & 2 & 90 & & & Yes & Yes & Yes & Yes \\
\hline 19 & AP & 50 & 10 & 6 & 8 & 50 & Yes & & & Yes & No & No \\
\hline 20 & AP & 50 & 10 & 6 & 8 & 50 & & Yes & & Yes & $\mathrm{No}$ & No \\
\hline 21 & AP & 50 & 10 & 6 & 8 & 50 & & & Yes & Yes & $\mathrm{No}$ & No \\
\hline 22 & AP & 90 & 4 & 2 & 2 & 90 & Yes & & & Yes & Yes & Yes \\
\hline 23 & AP & 90 & 4 & 2 & 2 & 90 & & Yes & & Yes & Yes & Yes \\
\hline
\end{tabular}


Table 7 Loan amount across quantiles under varying situations (Continued)

\begin{tabular}{|c|c|c|c|c|c|c|c|c|c|c|c|c|}
\hline 24 & AP & 90 & 4 & 2 & 2 & 90 & & & Yes & Yes & Yes & Yes \\
\hline 25 & GUJ & 50 & 10 & 6 & 8 & 50 & Yes & & & Yes & No & No \\
\hline 26 & GUJ & 50 & 10 & 6 & 8 & 50 & & Yes & & Yes & No & No \\
\hline 27 & GUJ & 50 & 10 & 6 & 8 & 50 & & & Yes & Yes & No & No \\
\hline 28 & GUJ & 90 & 4 & 2 & 2 & 90 & Yes & & & Yes & Yes & Yes \\
\hline 29 & GUJ & 90 & 4 & 2 & 2 & 90 & & Yes & & Yes & Yes & Yes \\
\hline 30 & GUJ & 90 & 4 & 2 & 2 & 90 & & & Yes & Yes & Yes & Yes \\
\hline
\end{tabular}


Table 7 Loan amount across quantiles under varying situations (Continued)

\begin{tabular}{|c|c|c|c|c|c|c|c|c|c|c|c|}
\hline \multirow[t]{2}{*}{ Case no. } & \multirow[t]{2}{*}{ DWELLD2 } & \multirow[t]{2}{*}{ SANITD1 } & \multirow[t]{2}{*}{ FAMTOT } & \multirow[t]{2}{*}{ CASTRDUM } & \multirow[t]{2}{*}{ PURPDUM } & \multirow[t]{2}{*}{ SECDUM } & \multirow[t]{2}{*}{ TCOST } & \multirow[t]{2}{*}{ RAINT } & \multicolumn{3}{|c|}{ LOAN AMT } \\
\hline & & & & & & & & & $10 \%$ & $50 \%$ & $90 \%$ \\
\hline 1 & No & Yes & 2 & No & Yes & Yes & 500 & 10 & 7089 & 30934 & 75653 \\
\hline 2 & No & Yes & 2 & No & Yes & Yes & 500 & 10 & 7804 & 44717 & 87152 \\
\hline 3 & No & Yes & 2 & No & Yes & Yes & 500 & 10 & 9405 & 44618 & 124442 \\
\hline 4 & Yes & Yes & 4 & Yes & Yes & No & 300 & 4 & 5579 & 22667 & 81223 \\
\hline 5 & Yes & Yes & 4 & Yes & Yes & No & 300 & 4 & 6294 & 36450 & 92723 \\
\hline 6 & Yes & Yes & 4 & Yes & Yes & No & 300 & 4 & 7894 & 36351 & 130012 \\
\hline 7 & No & Yes & 2 & No & Yes & Yes & 500 & 10 & 12198 & 36813 & 82157 \\
\hline 8 & No & Yes & 2 & No & Yes & Yes & 500 & 10 & 12913 & 50596 & 93656 \\
\hline 9 & No & Yes & 2 & No & Yes & Yes & 500 & 10 & 14513 & 50497 & 130946 \\
\hline 10 & Yes & Yes & 4 & Yes & Yes & No & 300 & 4 & 10687 & 28546 & 87727 \\
\hline 11 & Yes & Yes & 4 & Yes & Yes & No & 300 & 4 & 11402 & 42329 & 99227 \\
\hline 12 & Yes & Yes & 4 & Yes & Yes & No & 300 & 4 & 13003 & 42230 & 136516 \\
\hline 13 & No & Yes & 2 & No & Yes & Yes & 500 & 10 & 3238 & 23861 & 65198 \\
\hline 14 & No & Yes & 2 & No & Yes & Yes & 500 & 10 & 3952 & 37644 & 76697 \\
\hline 15 & No & Yes & 2 & No & Yes & Yes & 500 & 10 & 5553 & 37545 & 113987 \\
\hline 16 & Yes & Yes & 4 & Yes & Yes & No & 300 & 4 & 1727 & 15594 & 70768 \\
\hline 17 & Yes & Yes & 4 & Yes & Yes & No & 300 & 4 & 2442 & 29377 & 82268 \\
\hline 18 & Yes & Yes & 4 & Yes & Yes & No & 300 & 4 & 4042 & 29278 & 119557 \\
\hline 19 & No & Yes & 2 & No & Yes & Yes & 500 & 10 & 6284 & 9353 & 55307 \\
\hline 20 & No & Yes & 2 & No & Yes & Yes & 500 & 10 & 6999 & 23136 & 66806 \\
\hline 21 & No & Yes & 2 & No & Yes & Yes & 500 & 10 & 8600 & 23037 & 104096 \\
\hline 22 & Yes & Yes & 4 & Yes & Yes & No & 300 & 4 & 4774 & 1086 & 60877 \\
\hline 23 & Yes & Yes & 4 & Yes & Yes & No & 300 & 4 & 5489 & 14869 & 72377 \\
\hline
\end{tabular}


Table 7 Loan amount across quantiles under varying situations (Continued)

\begin{tabular}{|c|c|c|c|c|c|c|c|c|c|c|c|}
\hline 24 & Yes & Yes & 4 & Yes & Yes & No & 300 & 4 & 7089 & 14770 & 109666 \\
\hline 25 & No & Yes & 2 & No & Yes & Yes & 500 & 10 & 7272 & 55445 & 230534 \\
\hline 26 & No & Yes & 2 & No & Yes & Yes & 500 & 10 & 7987 & 69228 & 242034 \\
\hline 27 & No & Yes & 2 & No & Yes & Yes & 500 & 10 & 9588 & 69129 & 279323 \\
\hline 28 & Yes & Yes & 4 & Yes & Yes & No & 300 & 4 & 5709 & 42497 & 206908 \\
\hline 29 & Yes & Yes & 4 & Yes & Yes & No & 300 & 4 & 6423 & 56280 & 218408 \\
\hline 30 & Yes & Yes & 4 & Yes & Yes & No & 300 & 4 & 8024 & 56181 & 255697 \\
\hline
\end{tabular}


perspective, since the financial inclusion policy set by the government of India aims to ensure adequate and affordable credit flow even to resource-poor households. We see from this comparison that the loan off-take is skewed towards resource-rich households, whereas it should ideally be in the other direction. Table 7 also shows that even among borrowers in the $90^{\text {th }}$ quantile of the conditional loan distribution, marginal farmers received only approximately 80 percent of the loan amount of their counterparts who belong to the category of medium and large farmers (compare case 25 with case 27).

\section{Conclusions}

This study was motivated by the growing debate concerning the large-scale exclusion of rural households from the ambit of formal credit delivery channels, despite the continuous thrust of the state towards inclusive growth. Unlike studies that cover only limited geographical areas, this study includes six Indian states with varying institutional settings.

Several conclusions related to policy can be drawn from this analysis. First, the formal credit market in rural areas is sensitive to the characteristics of the village and the applicant's household and production. Second, there is considerable variation in the quantum of loans received from formal creditors. Third, even among borrowers in the $90^{\text {th }}$ quantile of the conditional loan distribution, marginal farmers received only approximately 80 percent of the loan amount of their counterparts belonging to the category of medium and large farmers. In other words, even where poor clients managed to access formal-sector creditors, the quantum of credit off-take is lower than that of their resource-rich counterparts. Therefore, despite government pushes for financial inclusion, the distribution of credit from the formal financial sector remains skewed towards resource-rich rural households.

\section{Endnotes}

${ }^{a}$ Households with operational land holdings of up to 1 hectare, above 1 hectare and up to 2 hectare, above 2 hectare and up to 4 hectare, and more than 4 hectare are termed marginal, small, medium, and large farmer, respectively. Though medium farmer and large farmer are separate categories in government documents, we have placed them together in this study as medium and large farmers (i.e., households with operational landholdings of more than 2 hectares).

${ }^{b}$ Mid-year rural population (source: Centre for Monitoring Indian Economy) divided by the total number of a commercial bank's rural branches (source: Quarterly Statistics on Deposits and Credit of Scheduled Commercial Banks, Reserve Bank of India) and cooperative societies (source: Trend and Progress of Banking in India, Reserve Bank of India).

${ }^{\mathrm{c} S}$ Scheduled commercial banks (SCB) comprise those banks that are registered under the second schedule of India's central bank (i.e., Reserve Bank of India's Act, 1934). They include both public and privately owned banks. Their operation is mostly spread over multiple districts and even across states.

${ }^{\mathrm{d}}$ Regional Rural Banks (RRBs) came into existence in 1975, with their primary goal being to cater to rural clients. The operation of RRBs is limited to few 
districts. RRBs are jointly owned by the Government of India, the respective State Government, and the sponsor bank, which is either an SCB or State Cooperative Bank.

${ }^{\mathrm{e}}$ Cooperative banks are financial institutions wherein the customers are the owners. Primary agricultural cooperative societies (PACS) are localized units owned by local people who share a common interest and who are involved in deposit mobilization and lending activities. In cases where cooperatives are also engaged in non-financial activities such as the selling of agricultural input, the running of consumer stores, and the trading of agricultural output, these banks are known as Multi-purpose Cooperative Societies (MPACS).

${ }^{\mathrm{f}}$ Self Help Group (SHG) is a group of approximately 20 financially challenged people who belong to a common socioeconomic strata that have come together initially to save money and to use the corpus for lending among themselves. After a certain time period of savings, SHGs may approach the bank for a loan. This process obviates the need for marketable collateral, which banks usually ask to secure repayment, by instituting peer pressure and a group guarantee mechanism.

${ }^{\mathrm{g}}$ Microfinance Institutions (MFI) form groups of poor people and act as lenders to the groups after sourcing loan from other financial institutions such as commercial banks.

${ }^{\mathrm{h}}$ If a village is too large in terms of the number of households, some representative hamlets of that village (not exceeding 300 households) were used for complete enumeration. In such cases, only those households covered under complete enumeration constitute the population from which the sample was drawn.

i The elected head of a local village-level governance structure.

'During 2009-10: US\$1 = Indian Rupee (INR) 47.

\section{Additional files}

Additional file 1: Appendix 1. Distribution of lenders across sample villages in certain states in India.

Additional file 2: Appendix 2. Coding of ordered exogenous variables.

Competing interests

The authors declare that they have no competing interests.

\section{Acknowledgements}

The authors would like to thank the editor, two anonymous referees, Jeffrey B. Nugent and Vasant P. Gandhi for their valuable comments, which have led to substantial improvements to this paper. Authors have benefitted from conversations on this topic with Samar K. Datta and M.S. Sriram, as well as from the comments of the participants of the $88^{\text {th }}$ Annual Conference of the Western Economic Association held at Seattle. Authors are grateful to Samar K. Datta for making available the dataset used in this study. We also acknowledge doctoral fellowship and dissertation support grant extended to the first author by Indian Institute of Management Ahmedabad.

\footnotetext{
Author details

${ }^{1}$ Economics and Business Environment, Indian Institute of Management Raipur, GEC Campus, Raipur 352015, India. 2Production and Quantitative Methods, Indian Institute of Management Ahmedabad, Vastrapur, Ahmedabad 380015, India.
}

Received: 19 June 2013 Accepted: 12 May 2014

Published online: 25 June 2014

References

Bassett G, Chen H (2001) Quantile style: return-based attribution using regression quantiles. Empir Econ 26(1):293-305 Basu P (2006) Improving Access to Finance for India's Rural Poor. Manuscript No. 36448 The World Bank, Washington, D.C 
Boucher SR, Guirkinger C (2007) Risk, wealth, and sectoral choice in rural credit markets. Am J Agric Econ 89(4):991-1004 Buchinsky M (1998) Recent advances in quantile regression models: a practical guideline for empirical research. J Hum Resour 33(1):88-126

Burgess R, Pande R (2005) Do rural banks matter? Evidence from the Indian social banking experiment. Am Econ Rev 95(3):780-795

Carter MR (1989) The impact of credit on peasant productivity and differentiation in Nicaragua. J Dev Econ 31(1):13-36

Datta SK (2003) An institutional economics approach to the problems of small farmer credit in India. Working Paper 2003-07-01, Indian Institute of Management, Ahmedabad

Datta S, Ghosh A (2013) Explaining access to credit by rural households: results based on a study of several states in India. Working Paper 2013-02-03. Indian Institute of Management, Ahmedabad

Eide E, Showalter MH (1998) The effect of school quality on student performance: a quantile regression approach. Econ Lett 58(3):345-350

Gonzalez-Vega C (1984) Credit-rationing behavior of agricultural lenders: the iron law of interest-rate restrictions. In: Dale W, Adams D, Graham H, Von-Pischke JD (ed) Undermining Rural Development with Cheap Credit. Westview Special Studies in Social, Political and Economic Development series (pp.78-95). Westview Press, Boulder, Colo, London

Guirkinger C, Boucher SR (2008) Credit constraints and productivity in Peruvian agriculture. Agric Econ 39(2):295-308

Kochar A (1997) An empirical investigation of rationing constraints in rural credit markets in India. J Dev Econ 53(2):339-371

Koenker R, Bassett G (1978) Regression Quantiles. Econometrica 46(1):33-50

Koenker R (2005) Quantile Regression, 1st edition. Cambridge University Press, Cambridge

Nakamura H, Nakajima T (2011) A credit market in early stages of economic development. Econ Lett 112(1):42-44

National Sample Survey Organisation (2005) Household Indebtedness in India as on 30-06-2002, All-India Debt and Investment Survey, NSS 59th Round (January-December 2003), Report No.501 (59/18.2/2). Ministry of Statistics and Programme Implementation, Government of India. http://mospi.nic.in/Mospi_New/site/inner.aspx? status=3\&menu_id $=31$

Pal D, Laha AK (2013) Sectoral Choice of Credit in Rural India. IIMA Working Paper 2013-03-01 Indian Institute of Management, Ahmedabad

Pal S (2002) Household sectoral choice and effective demand for rural credit in India. Appl Econ 34(14):1743-1755

Reserve Bank of India Quarterly Statistics on Deposits and Credit of Scheduled Commercial Banks, various issues. http:// www.rbi.org.in/scripts/QuarterlyPublications.aspx?head=Quarterly\%20Statistics\%20on\%20Deposits\%20and\%20Credit \%20of\%20Scheduled\%20Commercial\%20Banks

Reserve Bank of India Trend and Progress of Banking, various issues. http://www.rbi.org.in/scripts/AnnualPublications. aspx?head=Trend\%20and\%20Progress\%20of\%20Banking\%20in\%20India

Sahu GB, Madheswaran S, Rajasekhar D (2004) Credit constraints and distress sales in rural India: evidence from Kalahandi District, Orissa. J Peasant Stud 31(2):210-241

Walter SD, Feinstein AR, Wells CK (1987) Coding ordinal independent variables in multiple regression analyses. Am J Epidemiol 125(2):319-323

Winkelmann R (2006) Reforming health care: evidence from quantile regressions for counts. J Health Econ 25(1):131-145

doi:10.1186/s40100-014-0009-y

Cite this article as: Pal and Laha: Credit off-take from formal financial institutions in rural India: quantile regression results. Agricultural and Food Economics 2014 2:9.

\section{Submit your manuscript to a SpringerOpen ${ }^{\circ}$} journal and benefit from:

- Convenient online submission

- Rigorous peer review

- Immediate publication on acceptance

- Open access: articles freely available online

- High visibility within the field

- Retaining the copyright to your article

Submit your next manuscript at $\boldsymbol{\sim}$ springeropen.com 